\title{
EVALUASI PENERAPAN AKUNTANSI PERSEDIAAN PADA PT XYZ CABANG SUMBAWA BESAR
}

\section{Evaluation of the Inventory Accounting Application at PT XYZ Branch of Sumbawa Besar}

\author{
Irawati $^{1}$, Sudrajat Martadinata ${ }^{1}$, Muhammad Nurjihadi ${ }^{2}$ \\ ${ }^{1}$ Program Studi Akuntansi, Fakultas Ekonomi dan Bisnis, Universitas Teknologi Sumbawa \\ ${ }^{2}$ Program Studi Ekonomi Pembangunan, Fakultas Ekonomi dan Bisnis, Universitas Teknologi Sumbawa
}

\begin{abstract}
This study aims to find out how the method of record accounting and calculate the value of the end inventory at PT XYZ, a motorcycle dealer. Moreover, the aim of this research is to determine whether those method and inventory valuation has been in accordance to PSAK 14 or not. This research is designed to use mix method (qualitative and quantitative method applied together). There are three kinds of motorcycle brand used as samples in this research which was chosen purposively, that are BT1, RV1 and VR1. The data in this research collected by conducting some interviews, direct observation, and literature study. The results of this study indicate that the method of record accounting applied by PT $\mathrm{XYZ}$ is Perpetual with FIFO inventory valuation system. Furthemore, the method adopted by the company is in accordance with PSAK 14 due to the spesific statement in PSAK 14 which states that by using the perpetual method of record accounting, the amount of the end inventory can be known at any time without any physical calculation. In addition, using the FIFO valuation method would resulted a larger value of the end inventory, it therefore resulting a lower HPP.
\end{abstract}

*) E-mail: Irawati7238@gmail.com

Keywords: record accounting method, valuation method, the end inventory, PSAK 14

\begin{abstract}
ABSTRAK
Penelitian ini bertujuan untuk mengetahui bagaimana metode pencatatan dan menghitung nilai persediaan akhir pada PT XYZ, sebuah dealer sepeda motor. Selanjutnya, tujuan penelitian ini adalah untuk mengetahui apakah metode pencatatan dan penilaian persediaan tersebut telah sesuai dengan PSAK 14. Metode yang digunakan dalam penelitian ini adalah gabungan antara penelitian kualitatif dan penelitian kuantitatif (mix method). Sampel yang digunakan dalam penelitian ini adalah 3 jenis sepeda motor dengan merek HN diantaranya BT1, RV1 dan VR1. Metode pengambilan sample yang digunakan adalah purposive sampling di mana pengambilan sample dilakukan berdasarkan kriteria-kriteria tertentu. Metode pengumpulan data yang dilakukan yaitu dengan wawancara, observasi dan studi kepustakaan. Hasil penelitian ini menunjukkan bahwa metode pencatatan yang dilakukan PT XYZ adalah metode Perpetual dengan metode penilaian persediaan secara FIFO. Metode yang diterapkan perusahaan sudah sesuai dengan PSAK 14 karena dalam PSAK 14 menyatakan bahwa dengan metode pencatatan perpetual maka jumlah persediaan akhir dapat diketahui setiap saat tanpa melakukan perhitungan fisik. Selain itu, apabila menggunakan metode penilaian secara $F I F O$ maka akan menghasilkan nilai persediaan akhir yang lebih besar sehingga HPP yang dihasilkan lebih rendah.
\end{abstract}

Kata Kunci :metode pencatatan, metode penilaian, persediaan akhir, PSAK 14

\section{Pendahuluan}

Indonesia merupakan salah satu negara berkembang yang sedang giat-giatnya melaksanakan pembangunan dalam segala bidang kehidupan, salah satunya dalam bidang teknologi transportasi. Menurut Khisty \& Lall (2006), transportasi memegang peranan penting dalam bidang perekonomian karena dapat memperlancar mobilitas manusia dan barang agar lebih efisien. Di sisi lain, pentingnya transportasi membuat para pengusaha menjadikan transportasi sebagai peluang dalam melakukan kegiatan bisnis. Salah satunya dengan mendirikan perusahaan yang bergerak dalam bidang penjualan dan pembelian berbagai jenis alat transportasi.

Untuk itu, dalam menjalankan kegiatan bisnis agar mencapai tujuan sesuai dengan yang diharapkan, perusahaan harus berupaya memanfaatkan seluruh sumber daya atau aset yang dimilikinya dengan sebaik mungkin agar mendapatkan laba yang maksimal (Soemarsono: 2005). Di samping itu, setiap perusahaan yang berorientasi mencari laba harus dapat mengelola perusahaan tersebut dengan seefektif dan seefisien mungkin sehingga dapat meminimalkan kerugian dan 
memaksimalkan laba untuk menunjang kemajuan usaha tersebut. Salah satu asset yang berperan dalam meningkatkan laba yaitu persediaan.

Menurut Sugianto (2013), kegiatan membeli dan menjual kembali persediaan merupakan kegiatan utama yang dilakukan oleh perusahaan dagang, sehingga sangat penting bagi perusahaan untuk memantau tingkat persediaannya dan memastikan bahwa persediaan yang tersedia di gudang mampu memenuhi permintaan konsumen. Namun di samping itu, perusahaan juga harus meminimalisir terjadinya penumpukan persediaan karena hal tersebut akan berdampak pada kerusakan dan kehilangan persediaan yang dapat dilakukan oleh pihak luar maupun karyawan perusahaan itu sendiri. Oleh karena itu, persediaan memerlukan pengelolaan yang baik mulai dari pemesanan, penyimpanan, hingga pengeluarannya dari gudang untuk kemudian dijual.

Dengan demikian, perusahaan perlu mengatur kebijakan yang tepat mengenai metode pencatatan dan penilaian persediaan sesuai dengan prinsip-prinsip akuntansi yang berlaku umum. Terkadang dalam penerapannya, metode pencatatan maupun penilaian persediaan belum dilakukan dengan baik yang disebabkan oleh beberapa faktor di antaranya kekurangan informasi terbaru, kurangnya pengetahuan dari pihak perusahaan, ataupun perusahaan sudah merasa cocok dengan metode yang digunakan selama ini sehingga mereka takut jika mengganti dengan metode yang baru akan sulit untuk menyesuaikan dengan sistem yang telah diterapkan oleh perusahaan selama ini (Barchelino: 2016). Metode pencatatan dan penilaian persediaan yang diterapkan oleh perusahaan juga tidak semuanya sesuai dengan ketentuan yang berlaku sebagaimana yang mengacu pada Standar Akuntansi Keuangan yang berlaku di Indonesia.

Pada Pernyataan Standar Akuntansi Keuangan (PSAK) No.14 dijelaskan tentang berbagai hal yang berkaitan dengan persediaan, di antaranya pencatatan persediaan, metode yang digunakan dalam penilaian persediaan dan lain sebagainya. Menurut IAI (2015) dalam PSAK (Pernyataan Standar Akuntansi Keuangan) Nomor 14 tentang persediaan menyebutkan bahwa metode pencatatan persediaan antara lain metode perpetual dan metode periodik. Sedangkan metode untuk menilai persediaan diantaranya metode FIFO (First In First Out) dan metode Average (rata-rata tertimbang). Metode pencatatan dan penilaian persediaan tersebut akan memudahkan manager dalam mengambil keputusan mengenai kapan pemesanan persediaan dilakukan dan berapa jumlah unit yang akan dipesan. Dengan demikian, penumpukan persediaan dapat dikontrol sehingga tidak menimbulkan biaya yang lebih besar, karena semakin sedikit biaya maka laba yang dihasilkan akan semakin besar.

Oleh sebab itu, penelitian terhadap persediaan penting dilakukan pada setiap perusahaan dagang salah satunya perusahaan dagang yang memasarkan alat transportasi, karena kebutuhan akan transportasi sangat dirasakan oleh masyarakat. Salah satu alat transportasi yang memiliki tingkat penjualan paling tinggi adalah sepeda motor. Hal tersebut terlihat pada tabel perkembangan jumlah kendaraan bermotor dari tahun 2011 hingga 2015 yang diperoleh dari BPS (Badan Pusat Statistik) Indonesia.

Tabel 1. Perkembangan jumlah kendaraan bermotor (2011-2015)

\begin{tabular}{|c|c|c|c|c|c|}
\hline \multirow{2}{*}{ Jenis kendaraan } & \multicolumn{5}{|c|}{ Tahun } \\
\hline & 2011 & 2012 & 2013 & 2014 & 2015 \\
\hline Mobil penumpang & $9,548,866$ & $10,432,259$ & $11,484,514$ & $12,599,038$ & $13,480,973$ \\
\hline Mobil bus & $2,254,406$ & $2,273,821$ & $2,286,309$ & $2,398,846$ & $2,420,917$ \\
\hline Mobil barang & $4,958,738$ & $5,286,061$ & $5,615,494$ & $6,235,136$ & $6,611,028$ \\
\hline Sepeda motor & $68,839,341$ & $76,381,183$ & $84,732,652$ & $92,976,240$ & $98,881,267$ \\
\hline Jumlah & $85,601,351$ & $94,373,324$ & $104,118,969$ & $114,209,260$ & $121,394,185$ \\
\hline
\end{tabular}

Sumber: BPS, 2016

Dari tabel di atas dapat diketahui bahwa jumlah kendaraan bermotor khususnya sepeda motor mengalami peningkatan dari tahun ke tahun dan merupakan salah satu jenis kendaraan yang jumlah penjualannya sangat besar dibandingkan mobil penumpang, mobil bus, dan mobil barang.
Dengan melihat peluang tersebut, para pengusaha tertarik untuk memasarkan sepeda motor di berbagai wilayah di Indonesia termasuk di Provinsi NTB (Nusa Tenggara Barat) khususnya di Kabupaten Sumbawa besar. Salah satu perusahaan yang memegang lisensi resmi untuk memasarkan sepeda motor di wilayah 
Sumbawa Besar yaitu PT XYZ, di mana sepeda motor menjadi persediaan yang dimiliki oleh perusahaan tersebut.

Sepeda motor yang dipasarkan oleh PT XYZ yaitu sepeda motor dengan merek HN. Sebagaimana dilihat pada tabel yang diperoleh dari AISI (Asosiasi Industri Sepeda Motor Indonesia) mengenai penjualan sepeda motor berdasarkan mereknya yaitu:

Tabel 2. Data Penjualan Sepeda Motor Per Desember 2016

\begin{tabular}{ccc}
\hline Pabrikan & Terjual & Persentase \\
\hline HN & 309.796 unit & $70.76 \%$ \\
YM & 118.078 unit & $26.97 \%$ \\
KW & 6.262 unit & $1.43 \%$ \\
SZ & 3.510 unit & $0.80 \%$ \\
TS & 118 unit & $0.02 \%$ \\
\hline
\end{tabular}

Sumber: AISI, 2016

Berdasarkan tabel di atas, penjualan sepeda motor dengan merek HN memiliki persentase penjualan paling banyak diantara penjualan sepeda motor merek lainnya. Dengan demikan, PT XYZ memiliki tantangan agar penjualan persediaannya tidak mengalami penurunan untuk tahun-tahun berikutnya dan tidak kalah saing dengan produk-produk lain. Maka dari itu, penerapan akuntansi persediaan dalam mencatat dan menilai persedian diharapkan dapat membantu manager PT XYZ dalam meningkatkan laba perusahaannya.

Di samping itu, berdasarkan penelitian Goenawan, et al (2011) yang melakukan penelitian pada PT Dirgantara Pancapersada Bandar Lampung menyatakan bahwa metode penilaian persediaan secara FIFO dapat memberikan perhitungan harga pokok penjualan yang lebih wajar dibandingkan dengan metode penilaian LIFO. Hal tersebut akan berpengaruh pada besar atau kecilnya laba yang akan diperoleh perusahaan. Dari hasil perhitungan menunjukkan bahwa metode penilaian FIFO yang menghasilkan harga pokok penjualan lebih rendah sehingga laba yang diperoleh perusahaan akan lebih tinggi dibandingkan dengan menggunakan metode penilaian $L I F O$.

Untuk itu, peneliti tertarik melakukan penelitian terhadap PT XYZ agar dapat mengetahui nilai persediaan akhir dan penerapan metode pencatatan dan penilaian persediaan menurut PSAK 14 oleh PT XYZ. Selain itu, penelitian serupa belum pernah dilakukan khususnya pada PT XYZ Cabang Sumbawa Besar. Sehingga dengan adanya penelitian ini, diharapkan agar pihak manager maupun pihak lainnya dapat memiliki wawasan tambahan dan sebagai bahan evaluasi untuk keberlangsungan perusahaan ke depannya.
Dari uraian di atas, jelas terlihat bahwa persediaan memiliki arti penting dalam suatu perusahaan terutama perusahaan dagang. Sehingga hal tersebut yang melatar belakangi penulis untuk mengangkat skripsi yang berjudul "EVALUASI PENERAPAN AKUNTANSI PERSEDIAAN PADA PT XYZ CABANG SUMBAWA BESAR".

Berdasarkan uraian tersebut maka dapat dirumuskan tujuan penelitian sebagai berikut:

1. Untuk mengetahui metode pencatatan dan menghitung nilai persediaan pada PT XYZ.

2. Untuk mengetahui apakah penerapan akutansi persediaan yang diterapkan oleh PT XYZ telah sesuai dengan PSAK 14

\section{Metodologi Penelitian}

Dalam melakukan penelitian ini penulis menggunakan metode analisis mix method (Metode Campuran) yaitu gabungan antara metode kualitatif dan metode kuantitatif. Metode analisis kualitatif yaitu metode pengolahan data dan pengumpulan data serta fakta yang relevan dan disusun secara sistematis serta ditarik kesimpulan dalam bentuk kalimat (Sambuaga, 2013). Dalam hal ini mendeskripsikan mengenai kebijakan perusahaan dalam melakukan pencatatan persediaan dengan sistem perpetual maupun periodic serta metode penilaian persediaan yaitu $F I F O$ dan average dengan mengacu pada PSAK 14 dan menentukan HPP berdasarkan metode penilaian persediaan oleh PT XYZ. Metode kuantitatif yaitu metode penelitian yang menggunakan angka-angka dan diperoleh hasil berupa simpulan atas rumusan masalah yang didapat dari pengujian hipotesis yangdirumuskan (Sambuaga, 2013). Dalam hal ini penulis melakukan perhitungan persediaan akhir menggunakan metode penilaian FIFO dan metode penilaian rata-rata

Objek penelitian. ini yaitu PT XYZ Cabang Sumbawa Besar. PT XYZ adalah perusahaan otomotif atau dealer kendaraan bermotor roda dua dengan merek HN. Populasi dalam penelitian ini yaitu seluruh jenis sepeda motor dengan merek HN yang dijual oleh PT XYZ. Sedangkan sampel dalam penelitian ini yaitu sepeda motor merek HN dengan jenis BT1, RV1 dan VR1. Teknik pengambilan sampel dalam penelitian ini yaitu purposive sampling. Teknik purposive sampling yaitu teknik pengambilan sampel secara sengaja, sampel yang diambil tidak secara acak melainkan ditentukan sendiri oleh peneliti (Sumalata, 2013). Alasan peneliti memilih sepeda motor merek HN dengan jenis BT1, RV1 dan VR1 sebagai sampel adalah karena penjualan maupun pembelian sepeda motor jenis tersebut lebih banyak serta harga dari produk yang dijadikan sampel tersebut adalah yang paling murah dibandingkan sepeda motor merek HN jenis lainnya. Sumber data dalam penelitian ini yaitu data primer dan data sekunder. Teknik dalam 
proses penelitian dan penulisan skripsi ini yaitu dengan menggunakan beberapa cara, diantaranya observasi, wawancara dan kepustakaan.
Langkah-langkah yang dilakukan peneliti dalam menganalisa data yang diperoleh adalah sebagai berikut:

a. Melakukan penilaian persediaan dengan metode berikut

Tabel 3. Kartu persediaan pada perusahaan dagang

\begin{tabular}{|c|c|c|c|c|c|c|c|c|c|}
\hline \multirow[b]{2}{*}{ Tgl } & \multicolumn{3}{|c|}{ Pembelian } & \multicolumn{3}{|c|}{ Penjualan } & \multicolumn{3}{|c|}{ Saldo } \\
\hline & $\bar{Q}$ & (a) & Jumlah & $\mathrm{Q}$ & (a) & Jumlah & $\mathrm{Q}$ & (a) & Jumlah \\
\hline 1 & & & & & & & $\mathrm{x}$ & $\mathrm{xx}$ & $\mathrm{xX}$ \\
\hline 2 & $\mathrm{x}$ & $\mathrm{xx}$ & $\mathrm{xx}$ & & & & $\mathrm{x}$ & $x x$ & $\mathrm{xx}$ \\
\hline & & & & $\mathrm{x}$ & $\mathrm{xx}$ & $x x$ & $\mathrm{x}$ & $x x$ & $\mathrm{xx}$ \\
\hline
\end{tabular}

Sumber: Martani, et al (2014)

Keterangan:

Q: Kuantitas

@: Biaya per unit

Persediaan Akhir = Persediaan awal + pembelian - penjualan

b. Menyesuaikan metode akuntansi persediaan dengan PSAK nomor 14 tentang persediaan

\section{Pembahasan}

A. Metode pencatatan dan penilaian persediaan.

1. Metode pencatatan persediaan oleh PT XYZ Berdasarkan hasil wawancara yang telah dilakukan dengan bagian manajemen persediaan, maka metode pencatatan persediaan yang digunakan oleh perusahaan adalah metode pencatatan secara perpetual karena perusahaan mencatat transaksi khususnya yang berkaitan dengan persediaan berdasarkan waktu kejadiannya, sehingga pencatatan persediaan pada PT XYZ berjalan secara kontinu dan dapat mengetahui permintaan pelanggan terhadap berbagai jenis persediaan tanpa harus melakukan perhitungan fisik. Menurut Lili (2011:75) pencatatan perpetual memberikan informasi yang akurat dan tepat waktu sehingga manajemen dapat mengambil keputusan dengan melihat laporan pencatatan persediaan, selain itu dengan menggunakan metode pencatatan ini perusahaan dapat merespon dengan lebih efektif pertanyaan-pertanyaan pelanggan seputar ketersediaan barang dan dengan demikian dapat menghindari terjadinya kehabisan stok barang sehingga manajemen perusahaan dapat mengendalikan tingkat persediaan dengan adanya laporan dari sistem pencatatan ini. Hal tersebut akan mengurangi terjadinya penumpukan persediaan karena pada dasarnya barang-barang yang dijual oleh PT XYZ adalah barang-barang yang berkaitan dengan teknologi yang dari hari keharinya teknologi berkembang dengan cepat sehingga apabila barang yang pertama masuk tidak segera dijual maka bisa terjadi penurunan harga barang sehingga perusahaan bisa merugi.

Berbeda dengan metode pencatatan secara periodik dimana perusahaan harus melakukan perhitungan fisik persediaan agar dapat menentukan jumlah persediaan akhir. Menurut Suhari (2011:59) akibat dari sistem pencatatan ini yaitu barang dagang yang tercatat dalam pembukuan perusahaan pada akhir periode adalah barang pada awal periode sehingga pada akhir periode nilainya harus dihitung kembali dengan persediaan akhir periode. Barang dagang akhir periode harus dihitung fisiknya secara langsung agar dapat menggambarkan nilai persediaan barang dagang yang sesungguhnya dalam laporan keuangan.

2. Metode penilaian persediaan

Persediaan akhir $=$ persediaan awal + pembelian - penjualan

Melalui serangkaian wawancara dengan bagian marketing perusahaan maka disebutkan bahwa PT XYZ merupakan salah satu perusahaan yang selalu berupaya meningkatkan volume penjualan dan daya saing harga jual agar konsumen dapat tetap setia. Jumlah persediaan akhir dicatat tidak berdasarkan hasil perhitungan fisik setiap akhir periode akuntansi. Setiap kali dilakukan pembelian barang, perusahaan akan mendebit akun persediaan, bukan akun pembelian. Setiap ada transaksi penjualan, selain membukukan penjualan sejumlah harga jual, juga dihitung dan dibukukan HPP dengan mendebit 
akun harga pokok penjualan dan mengkredit akun persediaan.

Selain itu, PT XYZ juga memperhatikan ketersediaan persediaan barang dagangannya. Metode penilaian persediaan yang digunakan oleh PT XYZ menyangkut kegiatan operasi perusahaan adalah berdasarkan metode penilaian $F I F O$ yang mengasumsikan nilai persediaan yang pertama dibeli akan dijual atau digunakan terlebih dahulu, sehingga unit yang tertinggal dalam persediaan akhir adalah unit yang dibeli dengan nilai yang paling baru. Hal ini dikarenakan nilai persediaan yang disajikan merupakan nilai yang didasarkan pada harga yang paling kini. Selain itu, perusahaan memiliki kartu persediaan untuk memudahkan bagian gudang dalam mengetahui jumlah persediaan dan melaporkannya kepada bagian pengadaan persediaan, hal ini memudahkan jika terjadi kekurangan persediaan. Adapun hasil perhitungan persediaan akhir berdasarkan transaksi pembelian dan penjualan yang terjadi pada PT XYZ selama tahun 2014, 2015 dan 2016 maka diperoleh persediaan akhir sebagai berikut:

\section{a. Metode FIFO}

Dari tabel perhitungan nilai persediaan akhir berdasarkan metode penilaian FIFO dan rata-rata, maka diperoleh hasil bahwa apabila penilaian persediaan dilakukan dengan menggunakan metode FIFO maka hasil dari persediaan akhir akan lebih besar daripada menilai persediaan dengan menggunakan metode rata-rata. Misalnya pada sepeda motor jenis BT1 tahun 2014 jumlah persediaan akhir tercatat sebesar Rp 637,200,000 sedangkan pada tahun yang sama apabila menggunakan metode penilaian rata-rata maka jumlah persediaan akhir tercatat Rp 635,570,319 sehingga terdapat selisih sebesar Rp 1,629,681. Begitu juga pada tahun-tahun berikutnya untuk persedian akhir sepeda motor jenis BT1.

Pada sepeda motor jenis RV1 juga diperoleh persediaan akhir sebesar Rp 560,000,000 apabila menggunakan metode penilaian FIFO sedangkan pada tahun yang sama diperoleh persediaan akhir sebesar Rp 559,680,539.5 apabila menggunakan metode penilaian rata-rata, sehingga terdapat seleisih sebesar Rp 319,460.5. begitu pula pada tahun-tahun berikutnya untuk sepeda motor jenis RV1. Sedangkan pada sepeda motor jenis VR1 pada tahun 2014 diperoleh persediaan akhir sebesar Rp 1,055,140,000 apabila menggunakan metode penilaian $F I F O$, sedangkan apabila menggunakan metode penilaian rata-rata maka diperoleh persediaan akhir sebesar Rp 1,054,231,289 sehingga terdapat selisih jumlah persediaan sebesar Rp 908,711, begitu juga pada tahun-tahun berikutnya untuk sepeda motor jenis VR1. Sehingga dapat disimpulkan bahwa jumlah persediaan akhir akan selalu lebih besar apabila menggunakan metode penilaian FIFO dibandingkan metode rata-rata. Perbedaan jumlah persediaan akhir tersebut nantinya akan mempengaruhi jumlah HPP perusahaan tersebut. Untuk lebih lengkapnya, perhatikan tabel 4 berikut

Tabel 4. Perhitungan persediaan akhir menggunakan metode FIFO (dalam rupiah).

\begin{tabular}{rrrrcr}
\hline Jenis & Tahun & Persediaan Awal & Pembelian & Penjualan & Persediaan Akhir \\
\hline \multirow{2}{*}{ BT1 } & 2014 & $392,500,000$ & $1,429,780,000$ & $1,185,080,000$ & $637,200,000$ \\
& 2015 & $637,200,000$ & $1833,510,000$ & $1,481,490,000$ & $989,220,000$ \\
& 2016 & $989,220,000$ & $1,918,920,000$ & $1,676,790,000$ & $1,231,350,000$ \\
RV1 & 2014 & $278,600,000$ & $1,161,580,000$ & $880,180,000$ & $560,000,000$ \\
& 2015 & $560,000,000$ & $1,799,700,000$ & $1,197,200,000$ & $1,162,500,000$ \\
& 2016 & $1,162,500,000$ & $2,172,700,000$ & $1,463,580,000$ & $1,871,620,000$ \\
VR1 & 2014 & $377,300,000$ & $1,848,180,000$ & $1,170,340,000$ & $1,055,140,000$ \\
& 2015 & $1,055,140,000$ & $2,245,900,000$ & $1,435,960,000$ & $1,865,080,000$ \\
& 2016 & $1,865,080,000$ & $2,456,670,000$ & $1,663,280,000$ & $2,658,470,000$ \\
\hline
\end{tabular}

Sumber: data primer yang diolah 
b. Metode Rata-rata

Tabel 5. Perhitungan persediaan akhir menggunakan metode rata-rata (dalam rupiah)

\begin{tabular}{rrrrcr}
\hline Jenis & Tahun & Persediaan Awal & Pembelian & Penjualan & Persediaan Akhir \\
\hline \multirow{2}{*}{ BT1 } & 2014 & $392,500,000$ & $1,429,780,000$ & $1,186,709,681$ & $635,570,319$ \\
& 2015 & $635,570,319$ & $1,833,510,000$ & $1,480,371,466$ & $988,708,853$ \\
& 2016 & $988,708,853$ & $1,918,920,000$ & $282,6534,031$ & $1,081,094,822$ \\
\multirow{2}{*}{ RV1 } & 2014 & $278,600,000$ & $1,161,580,000$ & $880,499,460.5$ & $559,680,539.5$ \\
& 2015 & $55,968,0539.5$ & $1,799,700,000$ & $1,198,642,695$ & $1,160,737,845$ \\
& 2016 & $1,160,737,845$ & $2,172,700,000$ & $1,474,939,184$ & $1,185,498,661$ \\
VR1 & 2014 & $377,300,000$ & $1,848,180,000$ & $1,171,248,711$ & $1,054,231,289$ \\
& 2015 & $1,054,231,289$ & $2,245,900,000$ & $1,588,817,893$ & $1,711,313,396$ \\
& 2016 & $1,711,313,396$ & $2,456,670,000$ & $1,718,688,991$ & $2,449,294,405$ \\
\hline
\end{tabular}

Sumber: data primer diolah, 2017

Tabel 5 diatas memberikan informasi bahwa, pada sepeda motor jenis RV1 juga diperoleh persediaan akhir sebesar Rp 560,000,000 apabila menggunakan metode penilaian FIFO sedangkan pada tahun yang sama diperoleh persediaan akhir sebesar Rp 559,680,539.5 apabila menggunakan metode penilaian rata-rata, sehingga terdapat seleisih sebesar Rp 319,460.5. begitu pula pada tahun-tahun berikutnya untuk sepeda motor jenis RV1.

Sedangkan pada sepeda motor jenis VR1 pada tahun 2014 diperoleh persediaan akhir sebesar Rp 1,055,140,000 apabila menggunakan metode penilaian FIFO, sedangkan apabila menggunakan metode penilaian rata-rata maka diperoleh persediaan akhir sebesar Rp 1,054,231,289 sehingga terdapat selisih jumlah persediaan sebesar Rp 908,711, begitu juga pada tahun-tahun berikutnya untuk sepeda motor jenis VR1. Sehingga dapat disimpulkan bahwa jumlah persediaan akhir akan selalu lebih besar apabila menggunakan metode penilaian FIFO dibandingkan metode rata-rata. Perbedaan jumlah persediaan akhir tersebut nantinya akan mempengaruhi jumlah HPP perusahaan tersebut.

\section{B. Penerapan PSAK 14 oleh PT XYZ}

Berdasarkan wawancara yang dilakukan maka diperoleh keterangan bahwa persediaan barang dagang yang ada pada PT XYZ adalah barang-barang yang diperoleh melalui pembelian dari PT DEF cabang Mataram. Setelah melakukan pembelian, perusahaan langsung menyimpan barang yang dibeli dan siap untuk dijual kembali kepada konsumen yang berada pada area penjualan PT XYZ cabang Sumbawa Besar. Dalam PSAK 14 paragraf ke 4 menyatakan bahwa persediaan meliputi barang yang dibeli dan disimpan untuk dijual kembali, misalnya, barang dagang dibeli oleh pengecer untuk dijual kembali. Jika dibandingkan dengan PSAK 14 maka benar adanya bahwa persediaan barang dagangan pada PT XYZ adalah barang yang dibeli dan disimpan untuk dijual kembali dalam kegiatan normal perusahaan.

Biaya persediaan terdiri dari seluruh biaya pembelian, biaya konversi, dan biaya lainnya yang timbul sampai persediaan berada dalam kondisi dan lokasi saat ini. Berdasarkan hasil penelitian yang dilakukan pada PT XYZ perusahaan memiliki biaya pembelian persediaan yang meliputi harga pembelian, bea masuk dan pajak lainnya, dan biaya pengangkutan, penanganan dan biaya lainnya yang secara langsung dapat diatribusikan pada biaya perolehan barang (sesuai dengan PSAK 14 paragraf ke 7).

Dalam PSAK 14 paragraf 21 terkait teknik pengukuran biaya persediaan seperti metode biaya standar atau metode eceran, demi kemudahan dapat digunakan jika hasilnya mendekati biaya. Dalam hal ini teknik pengukuran biaya yang dilakukan oleh PT XYZ berdasarkan keterangan yag diperoleh yaitu menggunakan metode eceran agar mempermudah perusahaan dalam mengukur jumlah persediaan yang banyak dan cepat berubah, dengan demikian metode yang diterapkan perusahaan sesuai dengan PSAK No.14.

Selain itu, dalam PSAK 14 paragraf 25 menyatakan biaya persediaan kecuali yang disebut dalam paragraf 23, dihitung dengan menggunakan rumus FIFO atau rata-rata. Entitas menggunakan rumus biaya yang sama terhadap seluruh persediaan yang memiliki sifat dan kegunaan yang sama. Berdasarkan hasil penelitian diketahui bahwa PT XYZ sudah menilai persediaan 
barang dagangan dengan menggunakan metode $F I F O$ karena pada dasarnya barang-barang yang dijual oleh PT XYZ adalah barang-barang yang berkaitan dengan teknologi yang dari hari keharinya teknologi berkembang dengan cepat sehingga apabila barang yang pertama masuk tidak segera dijual maka bisa terjadi penurunan harga barang sehingga perusahaan bisa merugi. Selain itu, persediaan yang dimiliki perusahaan merupakan persediaan yang mengalami perubahan model yang sangat cepat mengikuti kebutuhan dan permintaan konsumen serta penumpukan persediaan akan mengakibatkan timbulnya biaya yang semakin besar sehingga dapat mengurangi laba perusahaan.

Untuk metode pencatatan persediaan, perusahaan menggunakan metode pencatatan secara perpetual. PSAK 14 menyatakan dalam sistem pencatatan perpetual biaya persediaan akhir dan HPP selama tahun berjalan dapat ditentukan langsung dari catatan atas persediaan. Namun jika ada ketidakcocokan antara biaya persediaan pada catatan akuntansi dan nilai persediaan yang ditentukan melalui perhitungan fisik, maka jumlah persediaan dalam catatan akuntansi harus disesuaikan dan HPP dalam catatan akuntansi juga harus disesuaikan.

Pengungkapan informasi mengenai persediaan yang ada pada PT XYZ menurut pihak perusahaan diungkapkan melalui neraca pada bagian asset lancar untuk jumlah persediaaan, dan diungkapkan melalui laporan laba rugi untuk pengakuan sebagai biaya, sehingga dengan demikian pengungkapan yang dilakukan perusahaan telah sesuai dengan PSAK 14.

Dari evaluasi yang telah dilakukan dan bukti-bukti yang ada, dapat diketahui bahwa penerapan akuntansi persediaan pada PT XYZ telah sesuai dengan PSAK 14 sehingga laporan keuangan dapat lebih akurat.

\section{Kesimpulan}

Berdasarkan pembahasan di atas maka dapat disimpulkan bahwa:

1. PT XYZ melakukan pencatatan atas transaksi persediaannya menggunakan sistem pencatatan perpetual karena memudahkan perusahaan untuk mengetahui jumlah kuantitas atau saldo persediaan dan tidak melakukan stock opname atau perhitungan fisik persediaan karena setiap pembelian dan penjualan langsung dicatat dalam rekening persediaan. Metode $F I F O$ yang digunakan perusahaan pada akhir periode tercatat harga yang terbaru, sehingga persediaan akhir dinilai dengan harga pokok pembelian yang paling akhir.Metode penilaian FIFO memberikan perhitungan harga pokok penjualan yang lebih wajar yang akan berpengaruh pada besar kecilnya laba yang akan diperoleh perusahaan.
2. Berdasarkan evaluasi persediaan yang dilakukan dan menyesuaikannya dengan PSAK 14 maka dapat disimpulkan bahwa penerapan PSAK 14 oleh PT XYZ telah sesuai sehingga laporan yang dibuat oleh perusahaan lebih akurat.

\section{Saran}

Berdasarkan pembahasan dan kesimpulan di atas, maka penulis menyarankan agar:

1. PT XYZ sebaiknya mempertahankan penggunaan sistem pencatatan perpetual dengan metode penilaian persediaan FIFO karena HPP yang dihasilkan lebih rendah sehingga laba yang dihasilkan akan lebih besar. Selain itu, sesuai dengan peraturan yang berlaku, yaitu UndangUndang perpajakan, apabila perusahaan menggunakan metode $F I F O$, maka perusahaan tidak perlu melaksanakan koreksi fiskal.

2. Biaya-biaya yang berkaitan dengan persediaan sebaiknya dicatat. Perusahaan dapat mengurangi biaya dengan cara menurunkan tingkat pembelian persediaan, tetapi di pihak lain, konsumen akan merasa tidak puas bila suatu produk stoknya habis. Oleh karena itu, perusahaan harus mencapai keseimbangan antara investasi persediaan dan tingkat pelayanan konsumen.

3. Selain itu, perusahaan diharapkan lebih memperhatikan faktor-faktor yang menyebabkan terjadinya biaya terkait persediaan barang dagangan seperti kerusakan, barang cacat, kadaluarsa dan lain-lain serta mengukurnya secara wajar dan mencatatnya dalam biaya lain-lain.

\section{Daftar Pustaka}

Baramuli, Friska \& Pangemanan, SS. (2015).“Analisis Sistem Akuntansi Persediaan Pada Yamaha Bima Motor Toli-toli”. Jurnal EMBA, 3 (3), 52-54

Barchelino, Rivaldo. (2016). “Analisis Penerapan Psak No. 14 Terhadap Metode Pencatatan Dan Penilaian Persediaan Barang Dagangan Pada Pt. Surya Wenang Indah Manado". Jurnal EMBA, 4 (1), 838-846.

Fahmi, Irham. (2013). “Analisis Laporan Keuangan”. Bandung: Alfabeta.

Goenawan; Susantolie, Alvina; Fiscal, Yunus. (2011). "Pengaruh Metode Penilaian Persediaan Terhadap Penentuan Harga Pokok Penjualan (Study kasus pada PT. Dirgantara Pancapersada di Bandar Lampung)". Jurnal Akuntansi \& Keuangan, 2 (1), 169-174. 
Hastoni. (2009). "Evaluasi Atas Akuntansi Persediaan Pengaruhnya Terhadap Laba Rugi Dalam Laporan Keuangan Pada Usaha Meubel”. Jurnal Ilmiah Ranggagading, 4 (1), 11-24.

Ikatan Akuntan Indonesia. (2015). "Standar Akuntansi Indonesia (SAK)”. Jakarta: Dewan Standar Akuntansi Keuangan.

Jusuf, AA \& Djakman, Chaerul, D. (2013). "Pengantar Akuntansi”. Jakarta: Salemba Empat.

Khisty, Jotin \& Lall, Kent. (2012). "Dasar-Dasar Rekayasa Transportasi”. Jakarta: Erlangga.

Kuswadi. (2015). “Meningkatkan Laba Melalui Pendekatan Akuntansi Keuangan \& Akuntansi Biaya”. Jakarta: Pt. Elex Media Komputindo.

Martani, Dwi; Veronica, Sylvia; Whardani, Ratna; Farahmita, Aria; Tanujaya, Edward; Hidayat, Taufik. (2015). "Akuntansi Keuangan Menengah Berbasis PSAK”, Jakarta Selatan: Salemba Empat.

Ma'roep, Maxi. (2014). "Penerapan Sistem Akuntansi Penjualan Pada Pt. Indomobil Surabaya”. Jurnal Ekonomi Bisnis (JEB), 3.

Ransun, Novita, Sari. (2015). "Analisis Akuntansi Persediaan Barang Dagang Berdasarkan PSAK No. 14 (Study Kasus Pada Pt. Enseval Putera Mega Trading Tbk). Skripsi. Manado: Kementrian Riset Teknologi Dan Pendidikan Tinggi Politeknik Negeri Manado.

Reeve, JM; Warren, CS; Duchac, Jonathan; Wahyuni, Ersa, Tri; Soepriyanto, Gatot; Jusuf, Amir, Abadi; Djakman, Charul, D. (2013). "Pengantar Akuntansi”. Jakarta. Salemba Empat.

Rondonuwu, Gabriella; Pangemanan, SS; Mawikere, Lidia M. (2016). "Evaluasi Penerapan Metode Persediaan Berdasarkan Metode Fifo Pada Pt. Honda Tunas Dwipa Matra Manado". Jurnal $E M B A, 4$ (4), 268-278.

Sadeli, LM. (2011). “Dasar-dasar Akuntansi”, Jakarta: Pt. Bumi Aksara.

Sambuaga, Reinhard, S. (2013).“ Evaluasi Akuntansi Persediaan Pada Pt. Sukses Era Niaga Manado”. Jurnal EMBA, 1 (4), 1697-1705.

Shatu, Yayah, Pudin. (2016). "Kuasai Detail Akuntansi Laba \& Rugi”. Jakarta: Pustaka Ilmu Semesta.
Soemarno, S,R. (2006). "Peranan Harga Pokok Dalam Penentuan Harga Jual”.Jakarta: Penerbit Rineka Cipta.

Sudjana, Adang. (2004). "Pengaruh Metode Pencatatan Perpetual Inventory Method Dan Physial Inventory Method Terhadap Laba Fiskal Dalam UU Pajak Penghasilan". Journal The Winners, 5 (2), 137-142.

Sugianto, Hardi. (2013). "Analisis Sistem Akuntansi Persediaan Barang Dagangan Pada Pt. Agung Automall Pekanbaru”. Skripsi. Riau: Universitas Islam Negeri Sultan Syarif Kasim.

Suhari, Michell. (2011). "Pelaporan Keuangan Sesuai Dengan Prinsip Akuntansi”. Jakarta: Pt. Gramedia Widiasarana Indonesia.

Sumalata, Vicky, Octavia. (2013). "Evaluasi Pengendalian Internal Dan Penerapan Akuntansi Persediaan Sparepart Pada PT. United Tractors". Jurnal EMBA, 1 (4), 1025-1028.

Susilawati, Anastasia, Endang, \& Sari, Ati, Retna. (2014).“Analisis Pencatatan Dan Penilaian Persediaan Sesuai Dengan PSAK No. 14 Pada Sarinah Department Store Basuki Rahmat Malang”. Journal riset mahasiswa xxxxxx, Xx (xx) 4-6.

Wibisono, Peter. (2015).“Analisis Metode Penilaian Persediaan Untuk Menentukan Tingkat Profitabilitas Pada Ud. Timbul Jaya Motor Kota Kediri”. Skripsi. Kediri: Universitas Nusantara PGRI.

Wibowo, Elisabeth, Maria, \& Iriyadi. (2014). "Pengaruh Persediaan Terhadap Peningkatan Profitabilitas Perusahaan". Jurnal Ilmiah Akuntansi Kesatuan (JIAKES), 2 (1), 2437-2440.

Yousida, Imawaty. (2013). "Sistem Akuntansi Persediaan Barang Ud. Kartika Motor Di Banjarmasin”. Jurnal KINDAI, 9 (2), 112-114. 